\title{
Mielen sairastaminen ja poikkeavuuden rajat
}

\author{
Lectio praecursoria Itä-Suomen yliopistossa 4.12.2020
}

\author{
Anna Kinnunen
}

$\mathrm{H}$ ulluus on ajankohtainen ja kiehtova aihe, josta keskustellaan tänään niin tieteessä kuin sen ulkopuolellakin. Sanana ja käsitteenä siihen on törmännyt viime vuosina esimerkiksi erilaisissa yleisötapahtumissa sekä televisiossa ja kirjallisuudessa. Katse on voitu suunnata joko menneeseen tai nykyisyyteen, jolloin keskustelu hulluudesta on ollut esimerkiksi mielisairaanhoidon historian tarkastelua tai pohdintaa nykyisestä mielenterveystyöstä ja -diagnooseista.

Minulle väitöskirjatutkijana viime vuosien keskustelu hulluudesta on ollut paitsi inspiraation lähde, myös merkki siitä, että olen tarttunut johonkin inhimillisesti ja yhteiskunnallisesti tärkeään ja askarruttavaan - johonkin sellaiseen, mitä on syytä pohtia ja avata tarkemmin.

\section{Mitä hulluus on?}

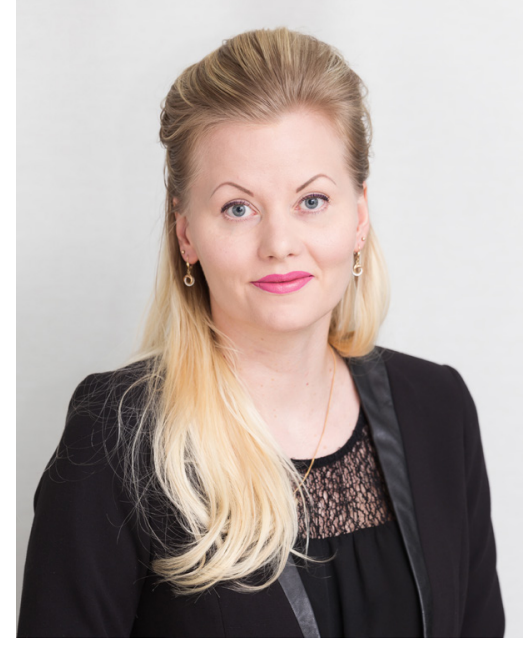

Anna Kinnunen

Kun minulta on viime vuosina yliopiston ulkopuolella kysytty, mitä tutkin, olen vastannut tutkivani joko hulluutta tai mielen sairastamiseen liittyviä käsityksiä. Molemmissa tapauksissa minulle on useimmiten vastattu, että kuulostaapa mielenkiintoiselta, mutta keskustelu on usein tyrehtynyt siihen. Aihe on siis herättänyt kiinnostusta, mutta toisaalta se on samalla saanut aikaiseksi myös hiljaisuuden - ikään kuin sopivia tai "oikeita" sanoja ei tuntuisi löytyvän.

Tämä kuvaakin hyvin aihepiirin kiehtovuutta: hulluudessa on jotain outoa ja vierasta, jotain, mitä on hankala sanoittaa ja jonka kiinnitämme herkästi johonkin muuhun kuin omaan tuttuun elämänpiirimme. Mutta samalla hulluudessa on kuitenkin jotain äärettömän kiinnostavaa ja puoleensa vetävää. Hulluus liittyykin mitä suurimmissa määrin myös meihin itseemme ja ihmisenä olemiseen.

Tieteen kielessä "hulluus" voidaan ymmärtää poikkeavuudeksi, jota on eri aikoina määritelty erilaisissa viitekehyksissä, kuten lääketieteen tai uskonnon näkökulmasta. Hulluus voidaan siis selittää esimerkiksi "mielisairaudeksi", mutta kun asiaa tarkastellaan historiallisesta tai 
kulttuurienvälisestä näkökulmasta, lääketiede on kuitenkin vain yksi monista hulluutta selittävistä tulkintakehikoista.

Myös arkikielessä "hulluus" on epäselvä käsite ja ilmiö, sillä siihen liittyy sekä myönteisiä että kielteisiä merkityksiä. Esimerkiksi ajatus hulluuden ja nerouden välisestä veteen piirretystä viivasta on meille kaikille tuttu. Voidaankin ajatella, että hulluudesta puhuttaessa ja sitä tutkittaessa liikutaan monenlaisilla rajoilla ja ihmisyyden filosofisten peruskysymysten äärellä.

Hulluus kytkeytyy esimerkiksi ruumiin ja sielun sekä luonnon ja kulttuurin väliseen erontekoon. On ajateltu, että henkisyys, eli sielu, erottaa ihmisen luonnosta, ja silloin kun sielu sairastuu, ihmisen on voitu ajatella menettävän osan ihmisyyttään. Tällainen ajattelumalli selittää osaltaan myös sitä, miksi mielen sairastaminen on koettu niin kokonaisvaltaisena ja häpeällisenä sairautena.

Kulttuurisesti "hulluus" voidaan siis ymmärtää ilmiöksi, jossa tunnustellaan paitsi terveyden ja sairauden myös ennen kaikkea normaalin ja poikkeavan välisiä rajoja. Tutkimukseni onkin avannut näkymiä tähän epäselvään ja jännitteiseen kulttuurisen rajankäynnin alueeseen.

\section{Johtolangoista punoutuva merkitysten verkko}

Tarkemmin määritellen tutkimukseni kohdistui mielen sairastamiseen kytkeytyviin kulttuurisiin käsityksiin. Kulttuuriset käsitykset ovat representaatiota, eli esityksiä tai edustuksia, jotka elävät kielessä ja kulttuurissa. Mielen sairaudet ja niistä kärsivät inmiset esitetään aina jonkinlaisina, jostakin tietystä näkökulmasta. Esitykset ovat tilannekohtaisia ja muuntuvia, mutta samalla todellisuuden esittämistä ohjaavat kuitenkin myös opitut mallit ja kulttuurin syvärakenteet.

Tutkimuksessani on siis ollut kyse sen selvittämisestä, millaisina mielen sairaudet ja niistä kärsivät ihmiset on oikeastaan esitetty, miksi ja kenen äänellä. Päätutkimuskysymyksenäni pyrinkin selvittämään, miten mielen sairastamiseen kytkeytyvät kulttuuriset käsitykset rakentuvat erilaisissa teksteissä ja konteksteissa ja, toisekseen, millaisia merkitysten siirtymiä käsitysten välille on mahdollista hahmottaa.

Ajallisesti olen liikkunut noin sadan vuoden säteellä 1900-luvun alun ja 2000-luvun alun välillä. Ajanjakso on kiinnostava, sillä sille paikantuu monia keskusteluita ja ideologioita, jotka ovat muokanneet käsityksiämme mielen sairastamisesta. Esimerkiksi vuosisadan alkupuolella keskustelua leimasivat (rotu)hygieeniset näkemykset, kun taas vuosisadan puolivälin jälkeen painopiste siirtyi sosiaalipsykiatriaan. Viime vuosikymmeniä taas on sävyttänyt keskustelu lisääntyvistä mielenterveysongelmista ja eräänlaisesta kulttuurin diagnosoitumisesta.

Tutkimusaineistoni koostin erityyppisistä tekstiaineistoista, jotka kertovat eri aikakausien ja eri toimijoiden ajattelusta. Tarkastelin kansankertomuksia, psykiatrisia sairauskertomuksia, vanhaa mielisairaalaa koskevaa muistelukerrontaa sekä elokuvaa eli audiovisuaalista kerrontaa.

Tein siis moniaineistoista tutkimusta, jossa pyrin ristivalottamaan mahdollisimman erilaisia aineistoja sekä liikkumaan ajassa siten, että katse tarkentuisi vuoroin vuosisadan taakse, 
vuoroin taas lähemmäs nykyaikaa. Näin pyrin hahmottamaan tutkimuskohteen ikään kuin tiheää luonnetta ja sen sijaintia eräänlaisessa kulttuuristen merkitysten verkostossa, jossa käsitykset rakentuvat suhteessa toisiinsa. Näin myös nykykeskustelut mielen terveydestä, sairaudesta ja poikkeavuuden määrittymisestä muuttuivat vähitellen ymmärrettävämmiksi.

\section{Ruumiin ja mielen rajat käsitystemme rakentajina}

Erilaisten aineistojen ristivalottaminen nosti esille, että mielen sairastamiseen liittyvät käsityksemme punoutuvat aina yksilöihin kohdistuviin odotuksiin sekä siihen, miten ymmärrämme ihmisenä ja yhteisön jäsenenä olemisen. Myös käsitykset ihmisruumiin ja -mielen ominaisuuksista nousivat esille.

Esimerkiksi kansankertomusten tarkastelu osoitti, miten käsitykset ihmisruumiin rajoista, puutteista ja kyvyistä ovat vaikuttaneet ajatteluumme. Kansankertomuksissa mielisairaus esitettiin usein niin kutsuttuna panentatautina, joka oli peräisin ihmisruumiin ulkopuolelta. Tällainen mielisairaus oli taikuudella nostatettu eli toisin sanoen se oli kanssaihmisten pahantahtoisen toiminnan seurausta.

Tällainen tulkintamalli edellytti käsitystä ihmisruumiin rajojen eräänlaisesta huokoisuudesta ja läpäisevyydestä. Ihmisruumis saattoi siis ikään kuin täyttyä sen ulkopuolelta lähtöisin olevalla sairaudella, mikä kuvastuu hyvin myös kertomuksista, joissa mielisairaus parannettiin oksennuttamalla se ulos. Käsitys ulkosyntyisestä mielisairaudesta vähensi yksilön omaa vastuuta sairastumiseen johtaneista syistä.

Toisaalta kansankertomuksista erottui kuitenkin toistuvasti myös sellainen kerronnan malli, jossa mielisairaus asetetiin pahan palkaksi. Esimerkiksi murhamiesten tai kirkon omaisuuden varastajien kerrottiin tulleen mielenvikaisiksi - samoin kuin sellaisten nuorten naisten, jotka olivat rietastelleet tai torjuneet ylpeästi kosijansa.

Tällaisessa kerronnassa ei niinkään ollut kyse mielisairauden selittämisestä vaan niin kutsutusta varoitusloresta, jolla välitettiin yhteisön käyttäytymisnormeja. Kyseessä onkin eräänlainen kulttuurin syväkerrostuma, jonka tiedostamattomien jäänteiden voi arvella vaikuttavan vieläkin, esimerkiksi siinä, että mielen sairastamiseen liitetään toisinaan edelleen häpeää ja salailua. Vanhassa varoitusloressa mielisairaan kuuluikin hävetä ja kärsiä, sillä sairaus oli oman toiminnan seuraus. Yhteisön muille jäsenille sen tuli toimia varoittavana esimerkkinä siitä, mihin ei kannattanut ryhtyä ja millainen ei kannattanut olla.

Siinä missä ruumiin rajat ohjasivat vielä vuosisata sitten ymmärrystämme mielen sairastamisesta ja sen syistä, nykykeskustelussa korostuvat usein käsitykset ihmisen mielestä ja siitä, mihin ihmismielen tulisi kyetä. Kun yhteiskunta modernisoitui, muuttuivat samalla myös käsitykset ihmisen olemuksesta ja rajoista. Esimerkiksi individualisoituminen korosti ihmisen kykyä ja vastuuta oman ruumiin sekä erityisesti oman mielen hallinnasta ja sen hyvinvoinnin vaalimisesta.

Onkin syytä kysyä, miten oman mielen terveyden ja tasapainon vaaliminen eräänlaisena kulttuurisena arvona ja velvoitteena vaikuttaa suhtautumiseemme niistä, jotka sairastuvat. Kun yksilöllisyys ja kyky oman mielen hallintaan korostuvat, ohjaako se meitä samalla etsimään erilaisten mielen häiriötilojen selitystä myös yksilöstä itsestään? Näyttäytyykö 
sairastaminen tällöin herkästi ihmisen omana syynä ja epäonnistumisena siinä, millainen ajan ihanneihmisen tulisi olla? Tällainen ajattelumalli ei lopulta olisi kovin etäällä vanhojen kansankertomusten varoitusloresta, jossa mielisairas esitettiin vastoin normeja ja ihanteita toimineena yksilönä, jonka sairaus oli itseaiheutettu.

\section{Kriittinen katse kulttuurin diagnosoitumiseen}

Tutkimukseni avasi näkökulmia myös siihen, miten lääketieteelliset sairausmääritykset verkottuvat aikaan ja kulttuuriin. Samalla hahmottui se, miten maallikot omaksuvat lääketieteen piiristä peräisin olevia käsityksiä ja millaisia vaikutuksia tällä on yksilöiden elämään.

Lääketieteen ja maallikoiden käsitysten vuorovaikutus on tärkeä ja ajankohtainen kysymys, sillä erityisesti nykyaikaa leimaa eräänlainen kulttuurin diagnosoituminen. Sillä voidaan viitata tilanteeseen, jossa diagnosoiva kieli omaksutaan arkipuheeseen ja tavaksi määrittää itseä ja toisia. Kulttuurin diagnosoitumista tulisi pohtia kriittisesti ja ymmärtää, miten se vaikuttaa esimerkiksi yksilöiden itseymmärrykseen ja käsityksiin siitä, mikä on normaalia ja mikä poikkeavaa.

Tutkimuksessani erityisesti itsetyydytyksen patologisointi osoitti, kuinka diagnostisen kielen omaksumisella on samanaikaisesti sekä myönteisiä että kielteisiä seurauksia. Yhdestä tarkastelemastani sairauskertomuksesta kävi ilmi, että potilas saattoi suhtautua harjoittamansa onaniaan ulkokohtaisesti ja analyyttisesti. Hän siis ikään kuin diagnosoi itsensä "onanistiksi", jolloin diagnoosi tarjosi selityksen potilaan kokemalle poikkeavuudelle. Samalla se auttoi potilasta jäsentämään omaa käyttäytymistä ja elämässä sattuneita epäonnistumisia.

Toisaalta itsetyydytyksen patologisointi aiheutti aikanaan myös suurta kärsimystä. Se tuotti kokemuksen oman toiminnan ja seksuaalisuuden poikkeavuudesta suhteessa siihen, millainen yksilön tulisi olla, miten tulisi toimia ja mitä välttää. Poikkeavuuden kokemus ajoikin potilaita jopa itsemurhan partaalle.

Myös nykypäivän kehyksessä on syytä kysyä, millaisia vaikutuksia diagnosoivalla kielellä sekä mielenterveysdiagnoosien määrän kasvulla on itseymmärrykseemme ja käsityksiimme normaaliuden rajoista. Yhtäältä diagnoosit avartavat normaaliuden skaalaa, sillä ne auttavat selittämään koettua poikkeavuutta ja tarjoavat sille syyn. Tällöin "poikkeavuus" merkityksellistyy "normaaliksi" reaktioksi esimerkiksi elämässä sattuneisiin vastoinkäymisiin.

Toisaalta inhimillisten ominaisuuksien patologisointi ja arkipuheeseen omaksuttu diagnostinen kieli saattavat kuitenkin myös kaventaa yksilön liikkumavaraa. Nykypäivänä esimeriksi epäsosiaalisuus, ujous ja herkkyys ovat piirteitä, jotka voivat määrittyä diagnostisen puheen kautta.

Voidaankin ajatella, että luomamme toimintaympäristö vaikuttaa aina merkittävästi siihen, miten sairaan ja terveen sekä normaalin ja poikkeavan raja kulloinkin määrittyy. Toimintaympäristömme asettamat vaatimukset saattavat saada jotkin inhimilliset ominaisuudet näyttäytymään ongelmallisina tai jopa patologisina piirteinä.

Esimerkkinä voidaan pohtia muistin ja kognitiivisten kykyjen korostumista nykyaikana. Tarkastelemieni 1930-luvun psykiatristen sairauskertomusten perusteella näyttäisi siltä, että 
tuolloin omaiset suhtautuivat varsin suopeasti esimerkiksi huonomuistiseksi, levottomaksi ja sekavaksi käyneeseen ikääntyneeseen läheiseensä, mikäli tämä kykeni yhä suoriutumaan arkiaskareistaan.

Tilanne ei välttämättä ole sama nykyaikana, sillä esimerkiksi yhteiskunnan digitalisoituminen edellyttää kognitiivista kyvykkyyttä myös varttuneessa iässä. Samalla korostuvat myös muistiin ja uuden tiedon omaksumiseen liittyvät vaikeudet. Tämä johtaa herkästi tilanteeseen, jossa ikääntyvä ja dementoivasta sairaudesta mahdollisesti kärsivä yksilö muuttuu nyky-yhteiskunnan ulkopuoliseksi ja vajavaiseksi "toiseksi".

\section{Kohti uusia kulttuurisia kertomuksia}

Kaikkiaan tutkimuksessani avautui näköaloja paitsi käsitystemme rakentumiseen myös siihen, miten suhtautumisemme mielen sairastamiseen ja poikkeavuuteen on muuttunut. Viimeisen puolen vuosisadan aikana keskustelu on avartunut mielen sairauksista pikemminkin mielen terveyteen, sen ylläpitoon ja niihin tekijöihin, jotka mahdollisesti rasittavat mielenterveyttämme. Samalla myös normaaliuden ja poikkeavuuden raja on käynyt entistä hämärämmäksi.

Yksi ajankohtainen tekijä, joka hämärtää normaaliuden ja poikkeavuuden rajoja nykypäivänä, on väestön ikääntyminen ja muistisairauksien lisääntyminen. Tämä on ajankohtaistanut ikivanhan ajatuksen eräänlaisesta vanhuuden ajan hulluudesta. Dementoitumisesta ja minuuden kadottamisesta on tullut uhkakuva, joka koskettaa yhä pidempään elävää nykyihmistä. Tällöin myös keskustelu normaaliuden ja poikkeavuuden rajoista ei enää kohdistu vain toisiin vaan mitä suurimmissa määrin myös meihin itseemme.

Myös tutkimukseeni sisältyvässä haastatteluaineistossa saatettiin painottaa, että "sitä ei tiedä, milloin sinne sairaalaan itse joutuu". Tällaisessa kerronnassa kuka tahansa meistä asetettiin potentiaaliseksi psykiatriseksi potilaaksi. Lisäksi haastateltavani välttelivät toistamasta mielisairaalapotilaiden poikkeavuutta uusintavia kerronnan malleja. He pyrkivät vakuuttamaan minut haastattelijana siitä, että potilaat olivat samanlaisia kuin kuka tahansa meistä.

Toisaalta tutkimukseni herätti kuitenkin myös kysymyksen siitä, missä määrin ainakin pintapuolisesti suopeampi suhtautuminen ja aiempaa avoimempi keskustelu mielenterveyden ongelmista koskee vakavia mielen sairauksia.

Esimerkiksi tarkastelemassani Prinsessa-elokuvassa päähenkilön kerrotaan sairastavan skitsofreniaa, mutta kuitenkin itse sairauden kuvaus jää elokuvassa taka-alalle. Yhtäältä se korostaa mielestäni kauniisti sitä, miten meissä kaikissa - niissäkin, jotka sairastavat vakavasti - on aina monia puolia ja että perimmäistä, absoluuttista poikkeavuutta ei ole olemassa. Toisaalta voidaan kuitenkin kysyä, kertooko tämä myös vaikeudesta kuvata ja sanoittaa vakavan sairauden kokemusta. Onko siis edelleen kyse eräänlaisten kulttuuristen resurssien puutteesta ja siitä, että edeltäviä kerronnan malleja ei ole tarjolla?

Yksi oman tutkimukseni keskeisimmistä tavoitteista onkin ollut luoda kulttuurisia resursseja käsitellä ja ymmärtää aihetta, josta puhuttaessa sanat tuntuvat katoavan ja keskustelu on latautunutta ja kiistanalaista. Kun lisätään ymmärrystä siitä, miten käsityksemme ovat rakentuneet ja mihin kaikkeen ne oikeastaan verkottuvat, voi ajan kanssa avautua mahdollisuuksia 
myös kyseenalaistaa ja kertoa toisin. Ja kun on kerrottu tarpeeksi monta kertaa toisin kuin edellä, voi lopulta syntyä kokonaan uudenlaisia kulttuurisia kertomuksia.

Kinnunen, Anna. 2020. Johtolankoja hulluuteen. Tutkimus mielen sairastamiseen kytkeytyvistä kulttuurisista käsityksistä. Kultaneito XX. Joensuu: Suomen Kansantietouden Tutkijain Seura. 